\title{
Audit Quality Effects on Earnings Management of Manufacturing Firms in Nigeria: A Comparative Study of Pre- and Post-International Financial Reporting Standard (IFRS) Period
}

\author{
Ejoh, Ndifon Ojong (Ph.D.) \\ Associate Professor of Accounting \& Finance, Department of Accountancy, \\ Cross River University of Technology, Calabar, Nigeria \\ Oko, Sylvanus Ushie (Ph.D.) \\ Senior Lecturer, Department of Accountancy, Cross River University of Technology, Calabar, Nigeria \\ Akpanke, Donnie Saint-manuel \\ Postgraduate Student, Department of Accountancy, Cross River University of Technology, Calabar, Nigeria
}

\begin{abstract}
This study examined the effect of audit quality proxied by Auditors' Independence (ADI), Audit Firm Size (AFS), Auditor Tenure (ADT) and Audit Firm Specialization (ADS) on shareholders' earnings (measured as Earnings per Share - EPS) and stock performance (measured as Market Price of Stock - MPS) of listed manufacturing companies in Nigeria, in the pre-and post-International Financial Reporting Standard (IFRS) periods. To achieve this, the study used eleven (11) listed manufacturing companies listed companies that had consistently published their audited annual financial reports from 2009 to 2018. Descriptive statistics, correlation analysis and Ordinary Least Square (OLS) univariate and multiple regression technique were adopted to analyse data obtained, with the ex-post facto research design employed in the methodology. The following results were obtained from the test of hypotheses. Auditors independence, audit firm size and auditors firm specialization have significant and positive impact on EPS and MPS. However, auditors' tenure was found to significantly affect both EPS and MPS negatively. The IFRS moderated model results revealed that audit quality variables have higher and more positive impact on EPS and MPS in the post-IFRS period, relative to the pre-IFRS, with their effects being statistically significant using the wald restriction test. The findings have direct implication on earnings management and stock performance in the Nigerian Manufacturing Industry.

Keywords: Earnings Per Share, Market Price, Auditors' Independence, Audit Firm Size, Audit Tenure, Audit Firm Specialization

DOI: $10.7176 /$ RJFA/10-24-03
\end{abstract}

Publication date: December $31^{\text {st }} 2019$

\subsection{INTRODUCTION}

Healy and Wahlen (1999) posit that firms intentionally manage earnings in financial reporting to either mislead shareholders about the entity's performance, or influence contractual outcomes that are based on accounting numbers. Income is often managed so that Earnings per Share (EPS) figures, which is the shareholders' income, reaches the desired levels. Prior literature shows that earnings are manipulated to ensure that EPS meets analysts' forecasts and meet the market earnings expectations. This is done because stock price is affected by investors' expectations concerning an entity's future cash flow (i.e., dividend paying) prospects. Since current EPS represents a signal of future cash flows, failing to meet analysts' forecasts of EPS often results in a depressed stock price while meeting these forecasts brings about a maintenance or growth in stock price (see Payne and Robb, 2000; Jordan and Clark, 2003).

Earnings are also managed to reach user reference points in EPS. Here, the object of manipulation is not to meet analysts' expectations of EPS but rather to achieve cognitive reference points such as zeros or fives in the two digital positions right of the decimal point (see Das and Zhang, 2003). This type of earnings management occurs when unmanipulated EPS falls only slightly below the user reference points. Discretionary accruals are used to increase income until EPS can be rounded up to these desired breakpoints. Although this type of manipulation is often referred to as Cosmetic Earnings Management (CEM), its results are fatal as Thomas (1989) notes that even "small changes in reported earnings (EPS) near user reference points have disproportionately large effects on perceived firm value".

Reasonable as these incentives to manage earnings might appear, it is generally assumed that earnings management is harmful to shareholders because of the implicit reduction in the transparency and reliability of financial reports (Beneish, 2001). Therefore, financial statement users consider earnings management to be unethical; and its occurrence should necessarily be prevented, by for example, relying on quality audit. A financial statement audited by dependable auditors' signals to the market that the financial statements, and the 
EPS figure are more reliable and dependable than those audited by unreliable auditors. The market perceives auditors' independence, size, tenure and specialist auditors to be of a higher quality than others, and rewards companies with larger improvements in share earnings, punishing those with decreased share earnings accordingly.

Auditors provide a critical role to capital markets through the delivery of statutory assurance to users of general purpose financial statements. Auditing reduces information asymmetries that exist between managers and firm stakeholders by allowing outsiders the opportunity to verify the validity of financial statements. The effectiveness of auditing, and its ability to constrain the management of earnings, is expected to vary with the quality of the auditor. Myers, Myers, and Omer (2003) propose that when audit quality is high, auditors constrain the self-serving choices that management would like to make in the presentation of financial statements. In comparison to low-quality auditors, high-quality auditors are more likely to detect questionable accounting practices and, when detected, to object to their use and/or to qualify the audit report. Thus, high-quality auditing acts as an effective deterrent to earnings management because management's reputation is likely to be damaged and firm value reduced if misreporting is detected and revealed. Therefore, increased audit quality could or should lead to increased quality of reported earnings and stock estimation, reflected in reliable EPS and stock pricing (Rusmin, 2010). Audit quality in this paper is measured using auditors' independence, Audit firm size, audit firm specialization and auditor's tenure.

Researches in finance and accounting have intensified since the universal declaration of IFRS. Approximately more than 120 countries have required or permitted the use of IFRS standards by publicly quoted companies (IASB, 2012). The decision to adopt IFRS in a wide and important economic area such as Nigeria cannot be over emphasised. IFRS brought a lot of changes in the way and manner the information contained in companies' financial statement is reported. For instance, the introduction of fair value principle, which is regarded as the most important implication of IFRS attracts and provokes researchers and generates several debates on the adoption of the standards. More clearly, IFRS requires the usage of fair value contrary to the book value as used by Nigerian Generally Accepted Accounting Principles (NGAAP). It is believed that fair value provides up-to-date information about assets as it reflects their real value. However, impairment test is carried on goodwill under IFRS, while it expected to be amortized under NGAAP. This implies that managers have more flexibility under IFRS and may intend to use their accounting decisions to manipulate impairment test of goodwill, which could affect the quality of reported earnings. The major concern about the conversion to IFRS is that it is more principle-based and there is a fear that the companies may apply the same rules differently thereby causing varying results.

Furthermore, principle-based standards give managers more flexibility to engage in earnings management and consequently resulting in high level of earnings manipulation (Callao, 2010). Thus, the very nature of accounting accruals gives managers a great deal of discretion in determining the earnings in any given period. Managers can apply legal and permitted accounting methods or practices which inevitably impacts negatively on earnings quality. Yet, other studies have claimed that IFRS reporting significantly reduces earnings manipulations. However, this view has not been fully supported by all academicians, regulators and the business communities as their evidence fail to support the hypothesis that IFRS reduces the level of earnings manipulation (Xu 2014; Mara, 2011; Berth, Landsman and Lang, 2008; Stolowy, 2008). IFRS being a principle-based reporting standard is not sufficient condition to reduce the level of earnings manipulation and it is obviously a fundamental fact that IFRS comes with a lot of changes in way and manner the information contained in the company's financial statement are reported, and the prior literature have provided mixed evidence on the impact of IFRS adoption. However, the fundamental question that is yet to be resolved in the literatures is: whether audit quality effects on earnings management and firm valuation is different in the GAAP reporting era and the current IFRS reporting period in Nigeria

\subsection{Research Objectives}

The broad objective of this study is to investigate the effect of audit quality on shareholders' earnings (EPS) of Nigerian listed Manufacturing firms. The specific objectives are:

i. To evaluate the effect of audit quality measured as auditors' independence, audit firm size, audit firm specialization and auditors' tenure on Shareholders earnings (EPS) of listed Manufacturing firms in Nigeria

ii. To investigate the differential effect of audit quality on shareholders' earnings in the Pre- and PostIFRS periods

\subsection{Research Hypotheses}

The following hypotheses are formulated in the null form for testing:

Ho1: Auditors' independence, audit firm size, audit firm specialization and auditors' tenure do not have any significant effect on Shareholders earnings of listed Manufacturing firms in Nigeria 
Ho2: The effect of audit quality on shareholders' earnings do not significantly differ for the pre- and post-IFRS periods of listed Manufacturing firms in Nigeria

\subsection{Literature Review}

\subsection{Theoretical framework}

Essentially, auditors' theory of inspired confidence, signaling theory, and agency theory justify the key function of auditing as a mechanism for mitigating information asymmetries among related parties.

Developed by the Limperg Institute in Netherlands in 1985, the theory of inspired confidence states that the auditor, as a confidential agent, derives his broad function in society from the need for expert and independent examination as well as the need for an expert and independent judgement supported by the examinations. Thus, auditors are expected to know and realize that the public continues to expect a low rate of audit failures. This requires that the auditors must plan and perform their audit in a manner that will minimize the risk of undetected material misstatements. The accountant is under a duty to conduct his work in a manner that does not betray the confidence which he commands.

The significance of the theory of inspired confidence is that the duties and responsibilities of the auditors are a derivation from the confidence that are bestowed by the public on the success of the audit process and the assurance which the opinion of the accountant conveys. Since this confidence determines the existence of the process, a betrayal of the confidence logically means a termination of the process or function. Carmichael (2004) in discussing the social significance of the audit stated that when the confidence that society has in the effectiveness and quality of the audit process and the audit report is misplaced, the value relevance of that audit is destroyed. Therefore, auditors are expected to maintain reasonable quality assurance especially given that an audit failure is effectively a career-ending event. Audit provides assurance to the owners and management of companies and to investors and stakeholders, and along with financial reporting, corporate governance and regulations, supports confidence in the capital markets.

Signaling theory suggests that companies with good performance use financial information disclosure to send signals to the market. Craven and Marston (1999), show that firms will attempt to accept the same level of disclosure as similar firms operating in the same industry since if a firm does not keep up with the same level of disclosure as others, it may be perceived by stakeholders that it is hiding bad news or negative information. As the types of financial statements produced have become standardized, potential information differentiation that a company can use to send a signal to the market through its financial statements is reduced. Companies are thus provided an incentive to signal, other than through transparency in their notes to the accounts and other voluntary disclosures, through their choice of auditor. Moreover, even voluntary disclosures that may be used as signals achieve enhanced credibility in the presence of a quality auditor.

Thus, a high quality audit sends a signal to the market that the financial statements are more credible than those audited by lower quality auditors. The market perceives audit firm size and specialist auditors to be of a higher quality than others and rewards (punishes) companies with larger improvements (or falls) in stock prices accordingly (Teoh and Wong, 1993; Krishnan \& Yang, 1999; Menon and Williams, 1994). It has been shown that the market's perception of the quality of the company's auditor influences that company's stock price. As such, directors and management may want to signal to the shareholders that their interest is being well monitored. Therefore, signaling should, theoretically, affect the demand for audit quality over and beyond the monitoring function alone. The positive Signal of transparency and credibility it sends to the market and the assurance it provides to stakeholders about the quality of earnings performance disclosures suggests a positive association between EPS and audit quality.

Again, signaling theory would suggest that the provision of voluntary IFRSs disclosures would give an indication of firms' decision-making process and financial behaviour (Eccles, Hertz, Keegan \& Phillips, 2001). For example, voluntary IFRSs disclosure may signify the intention of firms to distinguish themselves and give positive signals to market participants about their managerial ability and performance (Watson, Shrives \& Marston, 2002). The adoption of IFRS gives a positive signal of higher quality accounting and transparency (Tendeloo \& Vanstraelen, 2005) and would also lead to lower information asymmetry and cost of capital (Leuz \& Verrecchia, 2000). Similarly, the provision of quality accounting disclosures would tend to reduce the opportunities for earnings manipulation and enhance the stock market efficiency (Leuz \& Wüstemann, 2003). The higher disclosure requirements and financial reporting quality that stem from IFRSs implies that the adoption of IFRSs gives a positive signal to investors as information asymmetry and agency costs tend to diminish (Tarca, 2004).

\subsection{Conceptual Review}

Since the mandatory adoption of IFRS by a lot of countries in the world, a lot of effort has been put in research to determine the effect it has on key variables such as value relevance and earnings management. This section thus reviews the relevant theoretical and empirical literature in connection with the topic under study. 
There are generally two views of earnings management. Firstly, it is seen as a management tool used for fulfilling their responsibility of wealth maximization. Secondly, earnings management is considered as an alteration of economic events in order to mislead the users of financial statements. These two different perspectives have led to various definitions of earnings management in prior literature.

On the aspect of earnings management having a positive effect, earnings management is defined by Beneish (2001) as a way for managers to disclose their private expectations about the firm's future cash flows to investors. This was also supported by McKee (2005) who defined earnings as reasonable and legal management decision making and reporting intended to achieve stable and predictable financial results. Fields, Lys and Vincent (2001) were also in support of this view. On the perspective of earnings management having a negative effect, the following definitions are put forth.

Value relevance, on the other hand, is one of the proxies outside earnings management used in measuring financial reporting quality. According to Vishnani and Shah (2008), value relevance depicts the ability of accounting information in financial statements to explain how the stock market is measured. It is also the ability of information to capture of affect share value (Barth et al., 2001; Hellstrom, 2009).

\subsubsection{Audit Quality Measures}

According to International Auditing and Assurance Standards Board (IAASB, 2011), there has been a number of attempts to conceptualize "audit quality" in the past. However, none has resulted in a definition that has achieved universal recognition and acceptance. Audit quality is, in essence, a complex and multi-faceted concept. The classic definition of audit quality that is cited by most audit researchers is that of DeAngelo (1981) which states that audit quality is the market-assessed joint probability that a given auditor will both (a) discover a breach in the client's accounting system and (b) report the breach. The definition highlights two important aspects of audit quality: (1) the competence of the audit firm that determines how likely it is that a misstatement will be detected and (2) the independence and objectivity of the auditor that determines what the auditor is likely to do about a detected misstatement. This definition has been quite useful to audit quality studies.

Seyyed (2012) provides further explanation that audit quality could be a function of the auditor's ability to detect material misstatements and reporting the errors. Together with other similar definitions, they all emphasize on two of the most important aspects of audit quality, namely auditor ability or auditor effort, and auditor independence. Therefore, this stream of definitions is mainly about the auditors' quality.

1. Audit independence

Okolie and Izedonmi (2014) defined audit independence as an auditor's unbiasedness in taking decisions during an audit. Independence implies being free from inspiration, stimulus or guidance of which in the absence of independence, the value of the audit function will be greatly compromised. Prior studies suggest that high audit fees paid by a company to its external auditor enhances the economic ties between them and as such may compromise the independence of the auditor ( $\mathrm{Li}$ and $\mathrm{Lin}, 2005)$. This weakened unconventionality results in failed audit quality and gives room for earnings manipulations (Okolie and Izedonmi, 2014). In past studies, audit fees have been used to measure auditors' independence (Wooten, 2003).

An auditor's lack of independence increases the possibility of being perceived as not being objective. This means that the auditor will not likely report a discovered breach. Prior studies contend that high fees paid by a company to its external auditor increase the economic bond between the auditor and the client and thus the fees may impair the auditor's independence (Li \& Lin, 2005). The impaired independence results in poor audit quality and allows for greater EM (resulting in lower earnings quality and stock estimation).

\section{Audit Firm Size}

DeAngelo (1981) theorizes that larger firms perform better audits because they have a greater reputation at stake. In addition, because larger firms have more resources at their disposal, they can attract more highly skilled employees. Others have theorized that large auditors attract a fee premium because their greater wealth reduces clients' exposures in litigation. Others have theorized that there is no real audit quality difference, but the perception exists because large firms are well known and have gained a reputation for high quality. On the whole, the evidence is mixed, but it appears that there is some relationship between audit firm size and audit quality. Based on DeAngelo's (1981) reports, many other studies use auditor size (specifically Big8, Big6, Big5 or Big4 Vs non-Big8, non-Big6, non-Big5 or non-Big4) to differentiate audit quality levels (Krishnan, 2003).

3. Audit Firm Specialization

Auditor industry specialization is another attribute of audit quality which extant literature suggests could affect earnings management practices of firms. This is because industry specialist auditors are familiar with the business operations of the industry of their specialization and also possess industry relevant experience and knowledge that enables them to audit companies in the industry more effectively than their counterparts (Minutti-Meza, 2013; Sarwoko \& Agoes, 2014). The empirical link between auditor industry specialization and earnings management is documented by several studies, with more current ones contained in Jaggi, Gul and Lau (2012) 


\section{Auditor Tenure}

Auditor tenure is viewed as the length of time between auditor-client relationship (Okolie, 2014). A lengthy link between the auditor and his client may threaten unconventionality given developed familiarity. This may lead to less caution and compromise on the part of the auditor. Besides, a lengthy engagement may bring about less effort to signal the failings of internal control and risk sources (Okolie, 2014). Knapp (1991) established a linkage between audit tenure and competence. The objectiveness of an auditor in detecting anomalies increases in the first years of engagement but wanes with time, reaching its weakest level after 20 years of service (Okolie, 2014). There has been considerable decrease in number of years for auditor tenure. In the US, auditor tenure was reduced from seven to five years; the European Commission recommended a rotation of engagement partners every seven years; in France, auditors are chosen for six financial years, while in Nigeria audit engagement should not exceed three years (Okolie, 2014). For this study, auditor tenure will be proxied as length of auditorclient relationship using a dichotomous variable of " 1 "e if 3 years + and " 0 ", if otherwise.

\subsubsection{Earnings Management}

The accounting literature is yet to provide a universally accepted definition of the term "Earnings Management $(E M)^{e e}$. Earnings management arises when managers exercise discretion over accounting numbers, with or without restrictions. The discretion is exercised to either maximize firm value (shareholder's wealth) or to maximize the selfish interest of managers (opportunistic earnings management). Most of the literature on EM deals with rounding earnings to reach cognitive reference points in income (EPS). Brenner and Brenner (1982) indicate that humans possess only a limited amount of memory and, therefore, store only the most relevant information about a number in their minds. Thus, investors would tend to remember primarily the most important digits within a number. For example, Carslaw (1988) suggests that investors would remember N398 million in earnings by rounding it down to N390 million or perhaps even to N300 million. Therefore, to prevent investors from rounding earnings down when unmanipulated income falls only slightly below user reference points, management will find ways to manipulate earnings to round it up to just across the breakpoint. In the example above, management would round earnings up from N398 million to something slightly above N400 million.

Significant research across many time periods and countries shows that this form of EM occurs with great regularity (Jordan et al., 2008). All these studies examine the second earnings digit and indicate that this digital position contains abnormally lower rates of high numbers (e.g., eights and nines) and higher frequencies of small numbers (e.g., zeros and ones) than would be anticipated in unmanipulated earnings. All other numbers appear in the second earnings position at rates approximating their expected frequencies. From this result, each researcher concludes similarly that when the second earnings digit falls just below zero, management rounds income up so that the second digit just reaches or crosses over zero. The object of this manipulation is to increase the most important digit (i.e., the first digit) by one.

Thomas (2009) analyzes distributions of numbers in the right-most EPS digit (i.e., the digit two places right of the decimal point). He finds that for entities with positive earnings zeros and fives appear in this digital position far more often than expected. Das and Zhang (2003) examined the digital frequencies appearing in the position immediately right of the decimal point in the EPS numbers for a sample of companies. They conclude that their "evidence is consistent with managers manipulating earnings upward to round-up reported EPS." They further surmise that managers are more motivated to manipulate earnings to round up EPS when unmanipulated EPS numbers are close to behavioral benchmarks.

All three of the above studies examining digital patterns in EPS provide evidence of CEM in relation to EPS. More specifically, the research suggests that earnings are managed so that EPS can be rounded up to desirable reference points. Earnings Per Share (EPS) indicates the amount of net profit after tax (but before taking account of extra- ordinary income and expenses) attributable to each ordinary share in issue and ranking for dividend during the period. Shareholders are interested in this ratio because it indicates the amount of earning that will eventually be available to pay their dividends.

2.2.3 International Financial Reporting Standards effects on Earnings Management

Numerous studies have investigated the impact of IFRS adoption on earnings management but there is no general consensus on the kind of impact it has. Cai et al. (2008) reported a declining earnings management after the voluntary and obligatory IFRS adoption from his study of 32 countries from 2000 to 2006. Barth et al. (2008) who studied 21 countries reported decreasing earnings management, more value relevance of accounting information and timely loss recognition during the post IFRS adoption period. This result was also supported by Christensen, Lee and Walker (2008), who submit that earnings management declined and timely loss recognition increased after IFRS adoption in Sweden and Germany. Thus, their findings stipulate that companies that adopt a higher quality international financial reporting framework would eventually have a higher financial reporting quality.

Ashbaugh, LaFond and Mayhew (2003) who examined 17 European nations identified decreasing earnings management and they maintained that IFRS requires higher information disclosure which enhances manipulation 
risk of being detected, hence boosting the cost associated with earnings management.

Yahaya, Kutigi and Mohammed (2015) investigated the impact of IFRS adoption on earnings management behaviours of listed deposit money banks in Nigeria. They reported that the restriction to incur losses under IFRS substantially reduces the banks' ability to engage in earnings management.

\subsection{Empirical Review}

Okolie, Izedonmi, and Enofe (2013) examined the effect of audit quality on earnings management of companies listed on the NSE for the period 2006-2011. Using a sample of 57 manufacturing firms and regression analysis to analyze the data, the study documented a significant negative association between audit quality (proxy by audit firm size, audit tenure, audit fees, audit client importance) and discretionary accruals of the sampled companies.

Okolie (2014) investigated the relationship between audit quality and accrual-based earnings management of Nigerian firms. Using a sample of 57 non-financial firms listed on the NSE and the modified Jones model to measure discretionary accruals, the study documented a significant positive association between audit fees and discretionary accruals, and a negative association between audit tenure and discretionary accruals of Nigerian companies. Though the two Nigerian studies produced consistent results, there are also limited because all of them ignore the internal control aspect of audit quality (audit committee). Also, since the studies were not directly in relation to oil marketing companies in Nigeria, the findings are not likely to apply to oil companies in Nigeria due to sectoral differences between the sampled companies and oil companies in Nigeria.

Aliyu, Musa and Zachariah (2015) examined the effect of audit quality (represented by audit firm size, joint audit and auditor financial dependence - a measure of client importance) on earnings management of listed deposit money banks in Nigeria. Earnings management proxy by discretionary loan loss provision was estimated using Beaver and Engel (1996) model, tested by researchers such as Fiechter and Meyer (2011). The study used a sample of seven (7) deposit money banks listed on the NSE for the period of 2006 - 2013 while data analysis was done using ordinary least square (OLS) regression technique. Findings from data analysis indicated that both audit firm size and joint audit have significant negative effect on earnings management of listed deposit money banks in Nigeria. Auditor financial dependence had a significant positive effect on earnings management of listed deposit money banks in Nigeria during the study period. Though this study is from Nigeria, it is limited because given the peculiar nature of the banking sector; it is likely that its earnings management will be different from other sectors such as oil marketing companies not captured in the study sample. Consequently, some findings of the study may likely not apply to listed oil marketing companies in Nigeria. Also, findings from the study could be different from other sectors in Nigeria owing to the difference in the method of estimating discretionary accruals used for financial companies.

Recently, Tyokoso and Tsegba (2015) investigated the effect of audit quality on earnings management of listed oil marketing companies in Nigeria for the period 2004-2013. The dependent variable earnings management represented by Discretionary Accruals (DA) was estimated using the modified Jones model while the independent variable audit quality was represented by audit firm size, auditor industry specialization and auditor tenure. The findings of the study indicated that both audit firm size and auditor industry specialization have insignificant negative effect on DA of the sampled listed oil marketing companies in Nigeria during the period of study. In contrast, auditor tenure had a significant negative effect on DA of the companies.

Umoren and Enang, (2015) empirically examines whether the mandatory adoption of IFRS has improved the value relevance of financial information in financial statements of commercial banks in Nigeria. The sample comprises of twelve listed banks in Nigeria. Specifically, financial statement figures of 2010 and 2011 (preadoption period) and 2012 and 2013 (post-adoption) were utilized. Descriptive statistics and least square regression were conducted to analyse the effect of IFRS adoption on the accounting quality. The result indicates that the equity value and earnings of banks are relatively value relevant to share prices under IFRS than under the previous Nigerian SAS. Results also indicate that earnings per share is incrementally value relevant during post-IFRS period while book value of equity per share is incrementally less value relevant during the post-IFRS period.

Yahaya, Yusuf \& Dania, (2015) studied post-IFRS adoption value relevance of accounting information using two models. First, a price model which used proxies such as market price per share, book value of equity per share, earnings per share and cash flow per share. Second, a return model which used proxies such as annual return, earning per share, change in earning per share and the results showed that the explanatory power R2 for the price model specification is $84 \%$ for the total sample and that all coefficients are statistically significant. A comparison of coefficients indicates that the EPS of 3.47 has a higher explanatory power than any other variables. The results also demonstrate that explanatory power of accounting numbers increased from preadoption $(60 \%)$ to post-adoption (78\%). Similarly, Explanatory power (R2) for the return model specification is $13.4 \%$ for the total sample and just coefficient of EPS level is statistically significant. The explanatory power for the return model increased from pre-adoption (15.6\%) to post-adoption (16.4\%). According to both sub-samples just a coefficient of EPS level is statistically significant. So, the result of the return model also indicates adoption 
of IFRS improved relevance of accounting numbers in the deposit money banking sector. In view of these results, there is need for further study to explore the reasons for the superiority of EPS over BVEPS.

\subsection{RESEARCH METHODOLOGY}

\subsection{Design, Sample and Data}

The ex-post facto research design is adopted for this study based on positivist approach. An ex-post facto research design is used to describe the statistical effect of one variable on another. It is most appropriate for this study because it allows for testing of expected effects between audit quality proxies and shareholders' earnings of listed manufacturing companies in Nigeria and the making of predictions regarding such effects. The data for this study is obtained from secondary source. Secondary data were extracted from the published audited annual reports and accounts of the companies.

The population of the study comprises of all twenty-one (21) listed manufacturing firms on the Nigerian Stock Exchange (NSE) as at 31st December 2018 that are engaged in manufacturing activities. Having satisfied all the criteria used in filtering, eleven (11) firms serve as the sample of the study.

\subsection{Model Specification}

Multiple regression models are used to analyze the hypotheses to determine the impact of the predictor variables on the dependent variable. The Ordinary Least Square models for testing the first and second hypotheses are specified as:

$\mathrm{EPS}_{\mathrm{t}}=\beta_{0}+\beta_{1} \mathrm{ADI}_{\mathrm{t}}+\beta_{2} \mathrm{AFS}_{\mathrm{t}}+\beta_{3} \mathrm{ADT}_{\mathrm{t}}+\beta_{4} \mathrm{ADT}_{\mathrm{t}}+\mathrm{e}_{\mathrm{t}}$

Where; EPS $=$ Earnings per share, MPS $=$ Market price of shares, ADI =Audit Independence, AFS = Audit Firm Size, $\mathrm{ADT}=$ Audit Tenure, $\mathrm{ADS}=$ Audit Firm Specialization, $\beta_{0}=$ Constant term, $\beta_{1}-\beta_{3}=$ Unknown parameters to be estimated

The Ordinary Least Square models for testing the third and fourth hypotheses are specified as: $\mathrm{EPS}_{\mathrm{t}}=\beta_{0}+\beta_{1} \mathrm{IFRS}_{\mathrm{t}}+\beta_{2} \mathrm{ADI}_{\mathrm{t}}+\beta_{3} \mathrm{AFS}_{\mathrm{t}}+\beta_{4} \mathrm{ADT}_{\mathrm{t}}+\beta_{5} \mathrm{ADS}_{\mathrm{t}}+\beta_{6} \mathrm{ADI}^{*}$ IFRS $_{\mathrm{t}}+\beta_{7} \mathrm{AFS}^{*}$ IFRS $_{\mathrm{t}}+\beta_{8} \mathrm{ADT}^{*}$ IFRS $_{\mathrm{t}}+$ $\beta_{9}$ ADS $_{t} *$ IFRS $+e_{t}$

Where IFRS is a dummy variable, IFRS $=1$ for period between 2013-2018 (Post-IFRS), and IFRS=0 for period between 2007-2012 (Pre-IFRS). The coefficients of the interaction of IFRS with each audit quality variable represent the effect of audit quality variables on earnings in the post-IFRS period.

i. Shareholders' earnings measured as earnings per share (EPS). EPS is net profit after tax (but before taking account of extra- ordinary income and expenses) divided by ordinary share in issue.

ii. Auditors' Independence (ADI) is measured as auditors' fees divided by firm revenue.

iii. Audit firm size (AFS) is measured as " 1 " if the audit firm is in the Big-4, and " 0 " if otherwise.

iv. Auditor tenure (ADT) is proxied as length of auditor-client relationship using a dummy variable of " 1 "e if 3 years+ and " 0 "e, if otherwise.

v. Audit firm specialization (ADS) is measured as " 1 " if the audit firm is industry specialist familiar with the business operations and industry possess knowledge for effective audit, and " 0 " if otherwise. It is the final proxy of audit quality.

vi. International Financial Reporting Standards (IFRS) is a dummy variable, IFRS $=1$ for period between 2013-2018 (Post-IFRS), and IFRS=0 for period between 2007-2012 (Pre-IFRS).

\subsection{Results}

\subsection{Descriptive Statistics}

Table 1: Descriptive statistics of shareholders' earnings, market price of shares and audit quality proxies

\begin{tabular}{|l|c|c|c|c|c|}
\hline & EPS & ADI & AFS & ADT & ADS \\
\hline Mean & 2.4113 & 0.08267 & 0.7096 & 0.3588 & 0.8949 \\
\hline Median & 0.8211 & 0.00479 & 1.0000 & 0.0000 & 1.0000 \\
\hline Maximum & 11.850 & 0.61935 & 1.0000 & 1.0000 & 1.0000 \\
\hline Minimum & -6.3700 & 0.0006 & 0.0000 & 0.0000 & 0.0000 \\
\hline Std. Dev. & 3.4233 & 0.1727 & 0.4631 & 0.5143 & 0.4952 \\
\hline
\end{tabular}

The empirical predictions developed in this section is derive from the properties of shareholder's earnings, market price of stock and proxies of audit quality employed in the study. Therefore, the empirical analysis begins by providing descriptive statistics relating to these components. Table 1 provides statistics on the characteristics of average, median, maximum, minimum and standard deviation of the variables included in the study.

The table indicated an average value of 2.41 for EPS. The minimum and maximum values of EPS during the study period are 11.85 and -6.37 . These values imply that some sampled companies reported losses while others reported profits during the study period, with the average earning on shares being $214 \mathrm{k}$.

Similarly, the table shows that auditor independence (ADI) has a mean value of 0.083 during the study 
period. This value implies that only about eight (8) percent of the sampled manufacturing companies during the period of the study were audited by auditors without perceived independence, indicating that about 92 percent of the firms are audited by perceived independent auditors. The minimum and maximum values of auditor independence stand 0 percent and 61.9 percent respectively. Overall, the values indicate that most sampled firms have independent external auditors auditing their financial reports.

The table further revealed an average value of 0.71 for audit firm size (AFS). The value implies that about seventy-one (71) percent of the sampled manufacturing companies were audited by the big 4 audit firms in Nigeria (KPMG, PWC, Ernst and Young Delloitte) during the study period. The mean value of seventy percent further suggests that only 29 percent of the sampled companies were audited by non-big 4 audit firms in Nigeria during the period of investigation. This shows that the audit market in the sector is dominated by the big 4 audit firms in Nigeria and just a few non- big 4 audit firms audited these manufacturing companies in Nigeria. The minimum and maximum values of audit firm size during the study period were zero (0) and one (1) respectively. The minimum and maximum values of audit firm size indicate that auditor size is measured by a dummy variable which takes the value of one if the company is audited by a big 4 audit firm and zero if otherwise.

The descriptive results for audit tenure (ADT) revealed an average value of 0.358 . The value implies that about thirty-six (36) percent of the sampled companies had auditors who audited them for more than three (3) years during the study period, while about sixty-four (64) percent of the firms changed auditors within three years. The minimum and maximum values of audit tenure during the study period were zero (0) and one (1) respectively. The minimum and maximum values of audit tenure indicate that audit tenure is measured by a dummy variable which takes the value of one if the length of auditor-client relationship is 3 years + , and " 0 "e, if otherwise.

Data on audit firm specialization (ADS) reveals an average of 0.89 , indicating that about 89 percent of audited firms had auditors who were industry specific auditors, understanding the economic conditions and operations specific to the manufacturing industry. About $11 \%$ of the firm-year sample recorded auditors who were not industry specialists. This result is also relevant to the study in analysing the effect of using the audit services of audits who are specialists in the manufacturing industry.

Table 2: Pearson correlation coefficients matrix of audit quality proxies, EPS and MPS

\begin{tabular}{|l|l|l|l|l|l|}
\hline & ADI & ADS & ADT & AFS & EPS \\
\hline ADI & 1.0000 & & & & \\
\hline ADS & 0.0028 & 1.0000 & & & \\
\hline ADT & -0.0660 & -0.1636 & 1.0000 & & \\
\hline AFS & 0.2521 & -0.0891 & -0.3809 & 1.0000 & \\
\hline EPS & $0.7205 * * *$ & $0.2003 * * *$ & -0.0836 & $0.2976 * * *$ & 1.0000 \\
\hline
\end{tabular}

Table 2 presents correlation values between dependent and independent variables and the correlation among the independent variables themselves. These values are generated from Pearson Correlation output.

Auditor independence is positively correlated with EPS (0.705) of listed manufacturing companies in Nigeria during the study period. The high positive coefficient between auditor independence and EPS of the sampled firms in Nigeria suggests that auditor independence is associated with improved and reliable EPS figure of firms.

The table also revealed a positive correlation coefficient between audit firm specialization and EPS (0.2003) of the sampled manufacturing firms in Nigeria during the period of investigation. The significant positive coefficient between audit firm specialization and EPS of the sampled companies is an indication that auditors who are industry specialists are associated with reliable EPS figure of listed manufacturing companies during the study period. This relationship is not surprising because having knowledge, expertise and experience about the economic condition and the operations of the industry, will lead to more effective industry specific audit, thus, enhancing reliable earnings practices, reporting and disclosure.

The table further revealed a positive correlation coefficient between audit firm size and EPS (0.2976) of the sampled firms in Nigeria during the period of investigation. The significant positive coefficient between audit firm size and EPS of the sampled companies is an indication that audit firm size is associated with reliable EPS figure of quoted manufacturing firms during the study period. This relationship is not surprising because big 4 audit firms have the resources and capacity to perform high quality audit that is capable of producing reliable reported earnings firms.

However, auditor tenure is negatively associated with the EPS figure of sampled firms (-0.0628). The negative relationship between auditor tenure and EPS of Manufacturing companies in Nigeria shows that auditor tenure is associated with decrease in EPS figure credibility. This relationship is expected because lengthy link between the auditor and his client may threaten unconventionality given developed familiarity. This may lead to less caution and compromise on the part of the auditor. Besides, a lengthy engagement may bring about less effort to signal the failings of internal control and risk sources.

Finally, it is observed that among the proxies of audit quality, audit independence is positively related with 
audit firm specialization and audit firm size, implying that an independent audit review is associated with the industry specialty of the audit firm and how large the audit firm is (in terms of coverage).

\subsection{Test of Hypotheses}

Table 3: Average Slope (coefficient), t-statistics and $P$-value from annual Cross section regressions of hypothesis 1

\begin{tabular}{|c|c|c|c|c|c|c|c|}
\hline & Constant & ADI & AFS & ADT & ADS & R Sq. & Eqn \\
\hline coefficient & 0.42 & 13.78 & 3.175 & -0.628 & 4.196 & 0.66 & 1 \\
\hline t-statistics & & 7.989 & 2.924 & -0.962 & 3.692 & & \\
\hline p-value & & 0.0000 & 0.0339 & 0.3993 & 0.0195 & & \\
\hline
\end{tabular}

Table 3 reports univariate and multivariate regressions results estimated to test the study hypotheses 1 and 2 . The intercept, coefficients, $\mathrm{t}$-statistics, $p$-values and $\mathrm{R}$ squared are highlighted in each result.

4.3.1 Audit independence (ADI) effect on EPS and MPS

The regression result shows that ADI is a positive predictor of firm EPS. Stated differently, the more independent the auditors, the more reliable the EPS reported in the financial statements of Manufacturing firms in Nigeria. The effect is found to be about 13.78, implying that audit independence is regarded as audit quality, which allows for greater confidence of the market in the reported accounting numbers of firms. The t-statistics value of 8.436 and $p$-value of 0.000 less than the 0.05 alpha level shows that the effect is statistically significant. 4.3.2 Audit firm size (AFS) effect on EPS

The regression result shows that AFS has a positive effect on EPS figures of Manufacturing firms listed in the NSE. Stated differently, the larger the audit firm size, the higher the dependence on reported EPS, revealed by a positive coefficient of $3.175(p=0.03)$. This is because large audit firms have more resources to conduct high quality audits, have a large client base which makes them less dependent on any one client that could make them compromise their audit quality and also have more investment in reputation capital which is at stake if they are found to have compromised audit quality than small audit firms. This therefore enhances market confidence on reported EPS figures of manufacturing firms in Nigeria, Based on the result, audit firm size has significant effect on EPS of manufacturing companies in Nigeria.

4.3.3 Audit Tenure (ADT) effect on EPS

The regression result shows that ADT is a negative yet insignificant predictor of the EPS figure of Manufacturing firms in Nigeria (coefficient $=-0.628, p=0.3993$ ). Stated differently, the longer the tenure of an audit firm, the less reliable the EPS figure reported in the financial statement, which results in plummeting of share prices. This result implies that long auditor tenure is associated with less EPS. The result is expected because as the length of auditor- client relationship increases, familiarity with the audited firm may cause compromise, which threatens the reliability of reported EPS.

\subsubsection{Audit Firm Specialization effect on EPS and MPS}

Audit firm specialization has been found to affect EPS, with the effect being positive and statistically significant. The effect of ADS on EPS is given by a coefficient of 1.196 (with $t$-statistics $=3.692$ and $p=0.019$ ). The result is expected because Industry specialist auditors are familiar with the business operations of the industry of their specialization, and, also possess industry relevant experience and knowledge that enables them to audit companies in the industry more effectively than their counterparts. This makes the market rely more on the EPS figure published by the firms. The findings collaborate with the findings of Jaggi, Gul and Lau (2012). Based on the result, audit firm specialization has significant effect on EPS of Manufacturing companies in Nigeria.

Table 4: Average Slope (coefficient), t-statistics and $P$-value from annual Cross section regressions of hypothesis 2

\begin{tabular}{|c|c|c|c|c|c|c|c|c|c|c|c|c|}
\hline & constant & IFRS & ADI & AFS & ADT & ADS & ADI*IFRS & AFS*IFRS & ADT*IFRS & ADS*IFRS & $\begin{array}{l}R \\
R\end{array}$ & Eqn \\
\hline coefficient & 0.824 & 3.112 & 3.112 & 1.986 & -1.211 & 2.345 & 4.196 & 3.112 & 0.1134 & 4.214 & 0.81 & 2 \\
\hline t-statistics & & 2.981 & 4.21 & 2.824 & -1.111 & 3.712 & 3.218 & 2.9991 & 0.7684 & 7.239 & & \\
\hline$p$-value & & 0.002 & 0.0239 & 0.0413 & 0.0997 & 0.0219 & 0.0001 & 0.0211 & 0.1452 & 0.0001 & & \\
\hline
\end{tabular}




\subsubsection{Audit Quality Effect on EPS moderated by IFRS (The pre- and Pro-IFRS analysis)}

Panel A of table 4 shows the results of pre-and post-IFRS effects of audit quality implications on earnings per share. IFRS has a significant positive impact on EPS, with a coefficient of 3.236 (t-statistics $=2.981, P=0.002$ ). The findings conform with Yahaya et al (2015) who found that IFRS adoption reduces the earnings management behaviours of bank firms in Nigeria as the restriction to incur losses under IFRS substantially reduces the banks' ability to engage in earnings management.

The difference between the impact of audit independence on EPS in the pre-and post IFRS periods is about 1.084 (i.e. 4.196 (for post IFRS effect) minus 3.112 (for pre-IFRS effect)). The difference is significantly significant at the 0.05 level, using the Wald coefficient restriction test. Thus, there is a significant difference in the effect of audit independence on EPS in the pre- and post-IFRS

The difference between the impact of audit firm size on EPS in the pre-and post IFRS periods is about 1.126 (i.e. 3.112 (for post IFRS effect) minus 1.986 (for pre-IFRS effect)). The difference is significantly significant at the 0.05 level, using the Wald coefficient restriction test. The result holds that the effect of audit firm size in the post IFRS period is higher, and significantly different from the effect of audit firm size in the pre IFRS period.

The difference between the impact of audit tenure on EPS in the pre-and post IFRS periods is about not significant in the pre-and post-IFRS periods. The difference is not significant at the 0.05 level, using the Wald coefficient restriction test, indicating that the effect of audit firm tenure in the post IFRS period is not different from the effect of audit tenure in the pre IFRS period.

The difference between the impact of audit firm specialization on EPS in the pre-and post IFRS periods is about 1.869 (i.e. 4.214 (for post IFRS effect) minus 2.345 (for pre-IFRS effect)). The difference is significantly significant at the 0.05 level, using the Wald coefficient restriction test. The result holds that the effect of audit firm specialization in the post IFRS period is higher, and significantly different from the effect of audit firm specialization in the pre IFRS period.

\subsection{Conclusion}

The paper therefore reaches the following conclusions based on the stimulating result of data analysis and discussion:

The study provided empirical evidence on the association between audit quality (proxied by auditors' independence, audit firm size, and auditor tenure) and shareholders' earnings (proxied by EPS) of listed Manufacturing companies in Nigeria. Specifically, the study concluded that auditors' independence, audit firm size and audit firm specialization have positive and significant effect on EPS of Manufacturing companies listed in the Nigeria Stock Exchange. This indicate that auditors' independence, audit firm size and audit firm specialization constrain earnings management of the sampled firms, resulting in quality, credible and reliable EPS figure reported by the sampled firms, thereby increasing the value of the firm. The correlation analysis also supports this finding, with positive significant correlation coefficients results found between the said variables.

Overall, audit quality has significant effect on shareholders' earnings and market price of stocks, among listed Manufacturing companies in Nigeria.

Based on the findings of this study, Public companies (and more specifically the Manufacturing firms) should ensure that auditors they hire are regarded as large, independent, and industry specialists. This will ensure that the public relies on the EPS figure of such firms, which can in turn can affect their share pricing. Thus, for improved market confidence and share valuation of manufacturing firms, the role audit quality cannot be overemphasized.

Again, auditors should be rotated regularly to diminish the negative effects of protracted audit tenure on the market pricing of stocks in Nigeria.

Finally, investors and stakeholders should pursue more future signaling disclosures, that provide information of all earnings quality with their implication for future stock performance.

\section{REFERENCES}

Adelegan O. Y. (2002). An empirical analysis of the relationship between cash flows and dividend changes; $A$ Paper presented at the 23rd Annual congress of the European Accounting Association, Munich Germany, 5.

Aliyu, M. D., Musa, A. U., \& Zachariah, P. (2015). Impact of audit quality on earnings management of listed Deposit Money Banks in Nigeria. Journal of Accounting and Finance Management, 1(4), 1-16.

Allen, E., Larson C. \& Sloan, R. (2010). Accrual reversal, earnings and stock returns. The Accounting Review, 65 (1): 49-71.

Beaver, W., \& Engel, E. (1996). Discretionary behaviour with respect to allowances for loan losses and the behaviour of security prices. Journal of Accounting and Economics, 22, 177-206.

Behn, B. K., (2008). Audit quality and properties of analyst earnings forecasts. Accounting Review, 83(2), $327-$ 349. 
Brenner, G. A. \& Brenner, R. (1982). Memory and markets, or why are you paying \$2.99 for a widget? The Journal of Business, 55(1), 147-158.

Carslaw, C.A. (1988). Anomalies in income numbers: evidence of goal oriented behavior. The Accounting Review, 63(2), 321-327.

Casey, K. M. \& Anderson, D. C. (1999). Examining the impact of the tax reform act on corporate dividend policy: a new methodology. Journal of Financial Review, 34(3): 17- 28.

Clarkson, P. M. (2000). Auditor quality and the accuracy of managing earnings forecasts. Contemporary Accounting Research, 17 (4), 595 - 622.

Clinch, G., (2010). Audit quality and information asymmetry between traders. Accounting \& Finance, 52 (3), 743-765.

Colbert, G. \& Murray, D. (1998). The association between audit quality and auditor size: an analysis of small CPA firms. Journal of Accounting, Auditing and Finance, 13 (2), 135 - 150.

Craven, B. M. \& Marston, C. L. (1999). Financial reporting on the internet by leading companies. European Accounting Review, 8 (2), 321 - 333.

Das, S. \& Zhang, H. (2003). Rounding-up in reported EPS, behavioral thresholds, and earnings management. Journal of Accounting and Economics, 35 (1), 31-50.

Davidson, A. G., Stenning, B.W. \& Wai, W. T. (1984). Auditor concentration and the impact of interlocking directors. Journal of Accounting Research, 22 (1), 313 - 317.

Davidson, R. A. \& Neu, D. (1993). A note on association between audit firm size and audit quality. Contemporary Accounting Research, 9 (2), 479 - 488.

DeAngelo, L. E. (1981). Auditor size and audit quality. Journal of Accounting and Economics, 3, 183 - 199.

Dechow, P. \& Schrand, C. (2004). Earnings quality, The Research Foundation of CFA.

Dechow, P. M., Ge, W. \& Schrand C. (2009). Understanding earnings quality. Working paper, University of California, Berkeley, University of Washington.

Dechow, P., Sloan, R. \& Sweeney, A. (1995). Causes and consequences of earnings manipulations: an analysis of firm's subject to enforcement actions by SEC. Contemporary Accounting Research, 13, $1-36$.

Deis, D. R. \& Giroux, G. A. (1992). Determinants of audit quality in the public sector. The Accounting Review, 67 (3), $462-479$.

Ejuvbekpokpo A. S. \& Edesiri, G. O. (2014). Determinants of stock price movement in Nigeria: (evidence from the Nigerian stock exchange). Journal of Economics and Sustainable Development 5 (3), 1-7

Faris, N. S. (2010), Analysis the determinants of market stock price movements: An empirical study of Jordanian commercial banks. International Journal of Business and Management 5(10), 67-79

Geetha, E. \& Ti, S. M. (2015). A study on the factors influencing stock price, A comparative study of automobile and information technology industries stocks in India. International Journal Current Research and Academic Review, 3(3): 97 - 109.

Healy, P. M. \& Wahlen, J. M. (1999). A review of the earnings management literature and its implications for standard setting. Accounting Horizons, 13, $365-383$.

Hogan, C. E. (1997). Costs and benefits of audit quality in the IPO market: a self - selection analysis. The Accounting Review, 72 (1), 67 - 86.

IAASB (2011). Audit quality: An IAASB perspective. International Auditing and Assurance Standards, Board, NewYork.

Jordan, C. E. \& Clark, S. J. (2003.). Evidence on the level of corporate America's participation in the earnings game. The National Accounting Journal, 5(1), 61-70.

Jordan, C.E., Clark, S.J. \& Anderson, M. (2008). Unusual digital patterns in EPS: evidence on the association between earnings management and company characteristics. Journal of Business \& Economics Research, 6 (1), 31-40.

Jordan, C.E., Clark, S.J. \& Pate, G.R. (2008b), Earnings management to achieve cognitive reference points in income. Academy of Accounting and Financial Studies Journal, 12(3), 97-112.

Khan, T. (2006). Financial reporting disclosures: an international perspective (Unpublished), Victoria University, Australia.

Krishnan, G. V. (2003). Does Big 6 auditor industry expertise constrain earnings management? Accounting Horizons, 17 (Supplement), $1-15$.

Krishnan, J. \& Schauer, P. C. (2000). The differentiation of quality among auditors: evidence from the not-forprofit-sector. Auditing Journal of Practice and Theory, 19 (2), 9 - 26.

Krishnan, J. \& Yang, J. S. (1999). Auditor industry specialization and earnings response coefficient. Working Paper. Temple University, (April).

Larry, L. D., Yang, L. \& Paul, H. M. (2004). Earnings Management and Earnings Surprises: Stock Price Reactions to Earnings Components. Proceeding of Research Conference, University of Washington, 1 -35.

Lee, C., Alan, J. Marcus, Z. R. \& Hassan, T. (2011). Earnings Guidance, Earnings Management, and Share 
Prices. Seminar paper, delivered at Boston College 1-43.

Li, J. \& Lin, J. (2005). The relationship between earnings management and audit quality. Journal of Accounting and Finance Research, 12 (1), 1- 11.

Menike, M. G. P. D. \& Prabath, U. S. (2014). The impact of accounting variables on stock price: evidence from the Colombo Stock Exchange, Sri Lanka. International Journal of Business and Management, 9(5) 125 137.

Menon, K. \& Williams, D. D. (1994). The insurance hypothesis and market prices. The Accounting Review, 69, $327-342$.

Moreland, K. A. (1995). Criticisms of auditors and the association between earnings and returns of client firms. Auditing Journal, 14 (1), 94 - 104.

Myers, J. N., Myers, L. A., \& Omer, C. T. (2003). Exploring the term of the auditor-client relationship and the quality of earnings: A case for mandatory auditor rotation. The Accounting Review, 78(3), 779 - 799.

Okolie A. O., \& Izedonmi, F. I. O. (2014). The impact of audit quality on the share prices of quoted companies in Nigeria. Research Journal of Finance and Accounting, 5(8):150-166.

Okolie, A. O. (2014). Auditor tenure, auditor independence and accrual-based earnings management of quoted companies in Nigeria. European Journal of Accounting, Auditing and Finance Research, 2(2), 63-90.

Okolie, A.O., Izedonmi, F. O., \& Enofe, A. O. (2013). Audit quality and accrual-based earnings management of quoted companies in Nigeria. Journal of Economics and Finance, 2(2), 7-16.

Olawale, S. A. \& Olaniyi K. L. (2015). Equity share price determinants: a survey of literature. Arabian Journal of Business and Management Review, 5(3), 38-54.

Palmrose, Z. V. (1988). An analysis of auditor litigation and audit service quality. The Accounting Review, 64 (1), $55-73$.

Payne, J.L. \& Robb, S.W.G. (2000). Earnings management: the effect of ex ante earnings expectations. Journal of Accounting, Auditing and Finance, 15 (4), 371-392

Penman, S. \& Zhang, X. (2007). Accounting conservatism, the quality of earnings, and stock returns. The Accounting Review, 77 (2), pp.237-264.

Rusmin, R. (2010). Auditor quality and earnings management: Singaporean evidence. Managerial Auditing Journal, 25(7): 618-638. http://dx.doi.org/10.1108/02686901011061324.

Saunders, M., Lewis, P., \& Thornhill, A. (2007). Research methods for business students (4th ed). Pearson education limited, England.

Schauer, P.C. (2002), The effect of industry specialization on audit quality: an examination using bid-ask spreads Journal of Accounting and Finance Research, 10 (1), 76-86.

Schipper, K. (1989). Commentary on earnings management. Accounting Horizons (December): 91 - 102.

Subramanyam, K. R., \& Wild, J. (1996). Going concern status, earnings persistence, and informativeness of earnings. Contemporary Accounting Research 13: 251- 273.

Sweeney, A.P. (1994). Debt-Covenant violations and managers' accounting responses. Journal of Accounting and Economics, 17, $281-308$.

Taimur, S., Harsh, P. \& Rekha P. (2015) Analysis of factors affecting share prices: The case of Bahrain stock exchange. International Journal of Economics and Finance, 7(3), 23-36

Teoh, S. H., \& Wong, T. J. (1993). Perceived auditor quality and the earnings response coefficient. The Accounting Review, 68, 346 - 366.

Thomas, J. K. (1989), Unusual patterns in reported earnings. The Accounting Review, 64(4), 773-787

Titman, S. \& Trueman, B. (1986). Information quality and the valuation of new issues. Journal of Accounting and Economics, 8 (2), $159-172$.

Tyokoso, G. M. \& Tsegba, L, M. (2015). Audit quality and earnings management of listed oil marketing companies in Nigeria. European Journal of Business and Management, 7(29):34-42.

Umoren, A. O., \& Enang, E. R. (2015). IFRS adoption and value relevance of financial statement of Nigerian listed banks. International Journal of Finance and Accounting. 4(1), 1-7. http://doi.org/10.5923/j.ijfa.20150401.01.

Uwalomwa U., Uwuigbe, O. \& Ranti, O. B. (2015). Assessment of the effects of firms ${ }^{\text {ee }}$ characteristics on earnings management of listed firms in Nigeria. Asian Economic and Financial Review, 5(2):218-228

Wallace, W. A. (1987). The economic role of the auditor in free and regulated markets: a review. Research in Accounting Regulation, 1, 7 - 34.

Wooten, T. C. (2003). Research about audit quality. The CPA Journal (January), 2003, http://www.nysscpa.org. Retrieved: April 21, 2012.

Yahaya, O. A., Yusuf, M. J., \& Dania, I. S. (2015). International financial reporting standards' adoption and financial statement effects: Evidence from listed deposit money banks in Nigeria. Research Journal of Finance and Accounting, 6(12), 107-123. 